\title{
Invited review: impact of specific nutrient interventions during mid-to-late gestation on physiological traits important for survival of multiple-born lambs
}

\author{
S. A. McCoard ${ }^{1 \dagger}$, F. A. Sales ${ }^{2}$ and Q. L. Sciascia ${ }^{3}$ \\ ${ }^{1}$ Animal Nutrition and Physiology Team, AgResearch Grasslands, Private Bag 11008, Palmerston North, New Zealand 4472; ${ }^{2}$ Instituto de Investigaciones \\ Agropecuarias, Angamos 1056, Magallanes, Chile; ${ }^{3}$ Institute for Nutritional Physiology 'Oskar Kellner', Leibniz Institute for Farm Animal Biology (FBN) \\ Wilhelm-Stahl-Allee 2, 18196 Dummerstorf, Germany
}

(Received 27 July 2015; Accepted 6 January 2017; First published online 22 February 2017)

\begin{abstract}
To improve production efficiency, the sheep meat industry has increased flock prolificacy. However, multiple-born lambs have lower birth weights, increased mortality and reduced growth rate compared with single-born lambs. Lamb mortality is a major issue for livestock farming globally and solutions are required to increase survival to realise the value of increased flock fecundity. Nutrition during gestation can influence maternal-foetal placental nutrient transfer and thus foetal growth and organ/tissue development, as well as improve postnatal productivity. This review covers the challenges and opportunities associated with increased prolificacy, highlights gaps in our knowledge and identifies some opportunities for how targeted intervention with specific nutrients during mid-to-late pregnancy may influence lamb survival and productivity with a specific focus on pasture-based systems. This time frame was selected as intervention strategies in short-time windows post-pregnancy scanning and before lambing to improve lamb survival in high-risk groups (e.g. triplets) are likely to be the most practical and economically feasible options for pasture-based extensive farming systems.
\end{abstract}

Keywords: sheep, nutrients, survival, production, foetus

\section{Implications}

Improving lamb survival and performance is key to enhancing productivity of sheep farming enterprises worldwide. Pastoralbased production systems often present a challenging environment to manipulate nutrition due to difficult terrain, vast land masses and remote locations. The potential for targeted dietary interventions to influence a range of production phenotypes including survival, growth and meat production offers exciting opportunities to realise the value of increased ewe fecundity. Targeted nutritional interventions in critical developmental time windows may offer potential tools for farmers to improve lamb survival and production performance especially in multiple-born lambs.

\section{Introduction}

Perinatal lamb mortality is a major welfare and production issue for sheep farming systems worldwide. In Australia alone, the production costs are estimated at AU\$ $450 \mathrm{M}$

\footnotetext{
${ }^{\dagger}$ E-mail: sue.mccoard@agresearch.co.nz
}

with prevention costs estimated at AU\$ 100M (Lane et al., 2015). Perinatal mortality is a complex problem involving the interaction of nutrition, environmental factors, sheep genotype and management.

Pasture-based sheep production is a relatively low cost, efficient and sustainable system that enable countries like New Zealand to compete as a global exporter of food and fibre (Morris and Kenyon, 2014). In New Zealand, >95\% of the sheep diet is provided through grazed pasture and forage crops (Hodgson et al., 2005) or even higher in the hill country environments where topographical challenges limit the ability to feed supplements. With expansion of the dairy industry, sheep farming is now located in these more challenging hill country environments which is often of lower fertility and subject to climatic extremes (Morris and Kenyon, 2014). These changes in the farming system pose additional changes to identifying intervention strategies to improve lamb survival.

As there is minimal genetic control over litter survival, with the main source of variation being temporary environmental effects (Everett-Hincks et al., 2005), nutrition is probably one of the most important environmental effects that influences 
lamb survival and performance. As such, feeding management and/or strategic feeding systems may produce tools for farmers to improve lamb survival. Prior reviews have described the effect of nutrition during the peri-conceptional period on foetal programming and health (Oliver et al., 2007; Fleming et al., 2012), the role of the plane of maternal nutrition and foetal programming on production (Symonds et al., 2010; Kenyon and Blair, 2014), vascularity of nutrient transferring issues including the placenta (Vonnahme et al., 2015), the effect of maternal trace element and vitamin supplementation on the lamb (Rooke et al., 2008), the impact of amino acids (AA) in sheep production (McCoard et al., 2016) and the potential reasons for the lack of transfer of scientific knowledge into practice to improve neonatal survival in small ruminants (Dwyer et al., 2016). This review focusses on the impact of maternal supplementation with specific nutrients in the mid-to-late gestation period, the potential underpinning mechanisms involved and the potential opportunities to increase survival of multiple-born lambs in pasture-based grazing systems with a particular focus on placental nutrient transfer, birth weight, viability and thermoregulation.

\section{Production impact of multiple births}

Implementation of nutritional, genetic, management and health strategies by New Zealand sheep farmers has resulted in a $24 \%$ increase in the number of lambs born per ewe mated in the last 18 years (increase of $100 \%$ to $124 \%$ from 1990; Morel et al., 2008). However, lambing percentages $>200 \%$ have been described (Shorten et al., 2013), which are associated with a greater proportion of twin- and tripletborn lambs (Amer et al., 1999).

It is well accepted that twins and triplets have reduced birth weight which leads to higher mortality rates at lambing compared with singletons (Scales et al., 1986; Gootwine et al., 2007). An average mortality rate of $15 \%$ to $20 \%$ in twins and $25 \%$ to $40 \%$ in triplets has been reported in New Zealand (West et al., 2008; Stafford, 2013), with similar rates observed in Australia (Hinch and Brien, 2014) and other areas of the globe (Rowland et al., 1992; Dwyer, 2007). The first $24 \mathrm{~h}$ of life is critical for lamb survival, with nearly $50 \%$ of all mortalities occurring during this time frame (Dwyer, 2007). The negative relationship between lamb survival and number of lambs born highlights the importance of identifying strategies to increase lamb survival in multipleborn lambs to realise the value of the improvements in ewe fecundity.

\section{Intra-uterine growth restriction}

Intra-uterine growth restriction (IUGR) is common in multiple-born lambs and is a significant problem for agricultural animal production. The term IUGR is often used to describe a wide range of phenotypic outcomes in offspring that have experienced a restricted intra-uterine environment, and is defined as decreased intra-uterine growth velocity (Ergaz et al., 2005) and thus reduced foetal growth potential. Most studies have focussed on the target outcome of human health where IUGR is often a condition resulting from drastically reduced conceptus nutrient and oxygen supply in late gestation mainly resulting from placental insufficiency. The consequences of IUGR in multiple-born lambs include reduced foetal growth and thus birth weight, higher mortality rates (see review by Kenyon, 2008), reduced neonatal growth rate and lower muscle mass (McCoard et al., 1997). In addition, IUGR can result in permanent negative effects on growth, feed efficiency, body composition and thus poor finishing, meat quality and long-term health, thereby decreasing farmer profits (Wu et al., 2006; Kenyon and Blair, 2014).

\section{Placental development and nutrient transfer}

The primary determinant of foetal growth, and thus lamb birth weight, is the supply of nutrients which depends on placental transport as illustrated by the positive correlation between placental and foetal weight (Mellor, 1983). Sheep have a cotyledonary placentation where the exchange of nutrients and waste products happens at discrete sites called placentomes (Ford, 2000). These discrete units of foetalmaternal exchange are composed of foetal (cotyledon) and maternal (caruncle) components (Ford, 2000) which can be classified based on their shape (type $A$ to $D$ ) and may differ in their maternal-foetal exchange area, oxygen exchange efficiency and glucose transport (Fowden et al., 2006). Transport of nutrients across the placenta is determined by a range of factors including the concentration gradient between maternal and foetal blood, placental blood flow and metabolism, and specific membrane-bound transporter expression and activity.

In sheep, uterine capacity is a key factor limiting foetal survival and growth, especially when ewes are carrying multiples (Gootwine et al., 2007). Lower birth weights in multiple litters are associated with smaller placentae with reduced placentome number and weight per foetus in twin compared to singleton foetuses (McCoard et al., 2001; Rumball et al., 2008; van der Linden et al., 2013) and decreased total placental vascularity (Vonnahme et al., 2008), suggesting reduced placental nutrient transport. However, the smaller placentas associated with twins have been shown to be more efficient (van der Linden et al., 2013) which may be a function of compensatory changes in placental structure and function to deliver an adequate nutrient supply to the foetus to support growth (Rumball et al., 2008). The role of changes in placentome morphology on nutrient transport has not been evaluated directly and warrants further investigation.

Developmental changes occur in maternal and foetal plasma AA concentrations during pregnancy in sheep. Factors that influence maternal and foetal AA profiles include breed (Ashworth et al., 2011), the stage of pregnancy 
(Kwon et al., 2003) and maternal nutrient status (Kwon et al., 2004). We have reported that increased foetal growth in response to maternal arginine supplementation from 100 days of pregnancy to term (McCoard et al., 2013) is associated with improved placental growth, development and function (van der Linden et al., 2015). Twins have reduced plasma arginine, leucine, histidine and glutamine compared with singletons (van der Linden et al., 2013), which indicates that AA transport may differ between twin and single placentae and/or differential metabolism of the foetoplacental unit. The mechanism responsible for these differences is unclear however leucine, arginine and glutamine are known activators of the mechanistic target of rapamycin (mTOR) signalling pathway which is a placental nutrient sensor (Roos et al., 2007) that coordinates maternal nutrient availability and foetal nutrient supply (Jansson and Powell, 2006). In early pregnancy, this pathway plays an important role in the survival and development of the ovine conceptus (Kim et al., 2011) and in humans; placental mTOR signalling is markedly down-regulated during IUGR (Roos et al., 2007). Hyperthermia-induced growth restriction in sheep is also associated with perturbations in placental mTOR signalling (Arroyo et al., 2009). In other species, mTOR signalling controls placental $A A$ transport by regulating the expression of specific AA transporters (Roos et al., 2005 and 2007). Thus, the activation of placental mTOR signalling and AA transporter expression leading to increased foetal growth is a potential mechanism underpinning the effect of maternal arginine supplementation on ovine foetal growth.

Another potential mechanism mediating the effect of maternal arginine supplementation on foetal growth is placental metabolism of arginine into nitric oxide (NO) which is a major mediator of ovine placental-foetal blood flow during pregnancy (Rosenfeld et al., 1996). Arginine is the major substrate used for NO production and the two enzymes responsible for this process are inducible (iNOS) and constitutive (cNOS) nitric oxide synthase. Kwon et al. (2004) report that the activities of iNOS and CNOS and levels of NO peak in the intercotyledonary placenta, placentome and intercaruncular endometrium during mid-to-late gestation of Columbia crossbred ewes - a period of rapid foetal growth. In addition, it has been reported that treatment of Suffolk ewes, restricted to $50 \%$ NRC requirements with sildenafil citrate, dose-dependently increased total $A A^{\prime} s$ and polyamines in amniotic fluid, allantoic fluid and foetal serum without affecting values in maternal serum, and foetal weight in nutrient-restricted ewes (Satterfield et al., 2010). Sildenafil citrate works by inhibiting the enzyme that breaks down cyclic guanosine monophosphate, the metabolite produced by NO stimulation of guanylate cyclase, and which is responsible for tissue vasodilation. Interestingly, it has recently been shown that NO synthesis stimulates mTOR activation (Ito et al., 2013; Capobianco et al., 2015), suggesting that either of these pathways maybe involved in regulating ovine placental $A A$ transport, and potentially contribute to the differences in placental efficiency between twins and singletons. A greater functional understanding of the foetoplacental unit in relation to nutrient transfer in multiple-born lambs is required to develop nutritional intervention strategies to improve foetal outcome in sheep.

\section{Birth weight}

Birth weight is a key contributing factor to lamb mortality with low birth weight increasing a lamb's risk for starvation and exposure (Dwyer and Morgan, 2006). The birth weight of triplet-born lambs was reported to be $19 \%$ to $24 \%$ lower than twin-lamb birth weights (Morris and Kenyon, 2004; Everett-Hincks et al., 2005; Everett-Hincks and Dodds, 2008), and $36 \%$ to $40 \%$ lower than singles (Scales et al., 1986). Lower birth weight is associated with increased surface area to body-mass ratio and lower body energy reserves (Alexander, 1978) which can increase mortality when exposured to cold conditions (Dwyer and Morgan, 2006). The optimal birth weight range for lamb survival is 4 to $6 \mathrm{~kg}$ (Dalton et al., 1980; Morel et al., 2008).

Specific AA supplementation during pregnancy has been shown to enhance foetal growth, and thus birth weight in sheep. Notably, intravenous bolus injection with $155 \mu \mathrm{mol}$ arginine- $\mathrm{HCl} / \mathrm{kg}$ BW three times daily between 60 days gestation and birth increases birth weight in single and twin lambs from under-fed ewes (Lassala et al., 2010). However, while the birth weight of quadruplet lambs was increased when well-fed Booroola Rambouillet ewes were injected with an intravenous bolus of $345 \mu \mathrm{mol}$ arginine-HCl/kg BW, three times daily, from 100- to 21 days of gestation, the birth weight of triplets, twins or singletons was unchanged (Lassala et al., 2011). In contrast, when twin-bearing Romney ewes were given an intravenous bolus injection of $345 \mu \mathrm{mol}$ arginine- $\mathrm{HCl} / \mathrm{kg}$ bodyweight, three times a day, from 100 days gestation to birth, the birth weight of female but not male lambs was increased (McCoard et al., 2013) suggesting supplementation during the last 2 weeks of gestation may have the potential to influence the birth weight of twin-born lambs. Alternatively, the differences between these studies may reflect breed differences in their response to AA supplementation, or potentially an influence of the nutritional value of the basal diet despite both being formulated to meet or exceed National Research Council (NRC) requirements. Overall, these studies highlight the potential for specific AA supplementation during key developmental time windows (late gestation) to influence lamb birth weight which may have important consequences for survival, especially in lower birth weight lambs. The effect of supplementation with other AA beyond arginine on lamb birth weight has yet to be evaluated. Furthermore, delivery methods that enable delivery of AA via the diet to avoid rumen degradation such as rumen-protected formulations or AA analogues (McCoard et al., 2016) are required before practical evaluation of the impact of AA supplementation can be evaluated in pasture-fed multiple-bearing ewes on farm.

lodine deficiency can lead to lamb mortality (Sargison et al., 1998). Lamb birth weight is negatively affected by grazing ewes on kale crops during gestation, an effect which 
is reversed with maternal iodine supplementation during pregnancy (i.m.: iodised arachis oil; high $=400 \mathrm{mg}$, medium $=300 \mathrm{mg}$; Knowles and Grace, 2015). Kale is a complementary forage crop that has low iodine concentrations and contains glucosinolates that inhibit thyroid utilisation of iodine through releasing thiocyanate goitrogens (Stoewsand, 1995), therefore in this case, maternal iodine supplementation was correcting for iodine deficiency. However, provided dietary intake of $>0.2$ to $0.30 \mathrm{mg} \mathrm{l} / \mathrm{kg}$ dry matter is obtained (Grace and Knowles, 2010), dietary intake of iodine is usually adequate. Consistent with this notion, birth weight is unaffected by maternal iodine supplementation $(26.6 \mathrm{mg} /$ day in the diet) from 119 day gestation to term in ewes fed fresh silage (McGovern et al., 2015). Similarly, lamb birth weight was unaffected in twin- or triplet-born lambs from pasture-fed ewes supplemented with iodine (i.m. injection of $1.5 \mathrm{ml}$ iodised peanut oil 35 days postpartum) despite elevated maternal iodine levels throughout gestation (Kerslake et al., 2010). These studies suggest that provided ewes are not iodine deficient, supplementation with iodine during mid-to-late gestation is likely to have limited impact on survival of multiple-born lambs.

Maternal supplementation with polyunsaturated fatty acid (PUFA) increases gestation length in several species (reviewed by Capper et al., 2006) resulting in a more physiologically mature foetus at birth. However, supplementation with $12 \mathrm{~g} / \mathrm{ewe}$ per day algae-derived PUFA DHA in twin-bearing Targhee ewes in the last 30 days of gestation and early lactation had no effect on lamb birth weight (Keithly et al., 2011). Other studies have also demonstrated variable effects of trace elements and vitamins throughout gestation on lamb birth weight (reviewed by Rooke et al., 2008). However, studies where ewes are supplemented in the last trimester of gestation are scarce. Capper et al. (2005) reported that vitamin E supplementation $(500 \mathrm{mg} / \mathrm{kg}$; 6 weeks prepartum) of twin- and triplet-bearing ewes increased lamb birth weight. Supplementation of pasture grazing ewes deficient in cobalt with 0.03 or $0.06 \mathrm{mg}$ cobalt/ day via weekly drenching throughout gestation also increased lamb birth weight (Quirk and Norton, 1987). However, maternal supplementation with selenium, an antioxidant, had inconsistent effects (Hammer et al., 2011). More research is required to establish whether maternal supplementation strategies in mid-to-late gestation can benefit lamb birth weight in pasture-fed ewes where trace element and mineral status of the ewes is adequate. The practical considerations for maternal trace element supplementation to ewes in pasture-based systems has been reviewed elsewhere (Grace and Knowles, 2012).

\section{Neonatal vitality}

Lighter birth weight, newborn lambs or lambs with lower rectal temperatures exhibit reduced vigour (Dwyer and Morgan, 2006), and less drive to suckle (Alexander and Williams, 1968), which increased their risk of hypothermia (Dalton et al., 1980). Increased mortality and morbidity of multiple-born lambs has been linked to compromised immune function (Dønnema et al., 2015). Vitamin $\mathrm{E}$ is one of the micronutrients that may have an impact on immune functions and health. It protects biological membranes from oxidative damage by acting as scavengers of reactive oxygen species and is linked to IgG production (Huber, 1988). A number of vitamin $E$ supplementation studies have been conducted during mid-to-late pregnancy to assess the production performance of multiple-born lambs. Dønnema et al. (2015) have shown that oral vitamin E supplemented (360 IU/ewe per day; 6 to 7 weeks prepartum) Norwegian White Sheep with $\geqslant 3$ lambs have a significantly lower rate of stillbirths compared with control ewes. However, this was not observed in ewes with $\leqslant 2$ lambs, which is in agreement with a previous study conducted in twin-bearing Hardy Speckled Faces ewes orally supplemented with $200 \mathrm{IU}$ vitamin E per ewe per day for the last 8 weeks of gestation (Merrell, 1998). The mechanism of action is currently not known, however it could be linked to reduced oxidative stress or lack of $\lg$ stimulation in twin-bearing ewes (Daniels et al., 2000).

Long-chain PUFAs have also been used to assess their effect on lamb viability, as they are known to influence neuronal division, synaptic transmission and retinal development potentially improving early neonatal behaviour. Several studies have shown that supplementation of twin- and triplet-bearing ewes with PUFAs in the last 4 to 9 weeks of gestation improved lamb vigour (Capper et al., 2005 and 2006; Pickard et al., 2005 and 2008). For example, inclusion of 6 or $12 \mathrm{~g}$ of DHA from 9 weeks before lambing improved measures of lamb vigour including time to suckle and time to stand (Pickard et al., 2005 and 2008).

\section{Thermoregulation}

Brown adipose tissue (BAT) is a specialised fat store that is used by the newborn lamb to generate about $50 \%$ of the total heat produced (Symonds and Lomax, 1992; Satterfield and $\mathrm{Wu}, 2011)$, facilitating an effective adaptation to the cold challenge of the extra-uterine environment and preventing hypothermia (Alexander and Williams, 1968). Hypothermia is a major cause of on-farm lamb losses in the first few days of life (Everett-Hincks and Dodds, 2008). Low birth weight lambs exhibited lower rectal temperatures (Dwyer and Morgan, 2006), greater lactate concentrations (Stafford et al., 2007) and lower plasma thyroid hormone concentrations (Kerslake et al., 2010). These factors are known to negatively impact on the ability of a newborn lamb to maintain body temperature after birth and likely contribute to mortality (Kerslake et al., 2010). We have shown that during cold exposure there was a rapid decrease in heat loss in the newborn lamb (McCoard et al., 2014b). Therefore, increasing BAT stores and/or the activity of BAT has the potential to improve survival.

Rooke et al. (2008) reviewed the role of trace elements and vitamin supplementation of the ewe on various traits in the lamb including thermoregulatory capacity. Of the 
micronutrients evaluated (Cobalt, Copper, lodine, Iron, Manganese, Selenium (Se), Zinc, vitamins $A$ and $E$ and $n-3$ fatty acids), Se, vitamin $E$ and fatty acids were identified as the most likely candidates to improve lamb survival. Many of the studies undertaken have evaluated supplementation throughout pregnancy and/or have studied the responses in ewes fed a concentrate or a conserved forage-based diet, rather than within a pasture-based feeding system. As some diets are deficient in some micronutrients, for example lower vitamin $E$ levels in dry stored feeds compared with spring fresh forage (Kivimae and Carpena, 1973), many of the studies reported in the literature may have limited application to a pasture-based system. Trace element supplementation in pasture-fed ewes can improve lamb performance (Grace and Knowles, 2012) however specific evaluation of thermoregulatory capacity of the neonates following maternal supplementation has not been directly evaluated.

Specific PUFA such as linoleic acid are a key energy source for BAT in lambs (Lammoglia et al., 1999). However, twinbearing Taghee ewes supplemented with $12 \mathrm{~g} / \mathrm{ewe}$ per day of algae-derived DHA during the last 30 days of gestation had no effect on lamb thermogenesis (Keithly et al., 2011). In contrast, twin-bearing ewes fed rumen-protected fat which was high in saturated and monounsaturated fatty acids or high in $n-6$ - and n-3-PUFAs at a level of $2 \%$ or $4 \%$ for the last 40 days of gestation may improve cold tolerance in newborn lambs (Chen et al., 2007). It is important to note however, that when fed at $8 \%$ of the ewe diet, cold tolerance was markedly reduced coupled with reduced palmitate oxidation from BAT indicating decreased ability to oxidise fatty acids, independently of cytochrome c oxidase activity, GDP binding or uncoupling protein 1 (UCP-1) gene expression. These observations highlight the potential for PUFAs to increase thermogenesis but in a dose-dependent manner.

lodine supplementation of the ewe can elevate thyroid hormone level in the ewe and newborn lamb (Andrewartha et al., 1980; Rose et al., 2007) which may increase rectal temperatures in the lamb compared with supplemented lambs (Donald et al., 1994). Negative relationship between maternal iodine supplementation in late gestation and immunoglobulin $\mathrm{G}(\mathrm{lgG})$ levels in the newborn lamb have been reported (Boland et al., 2006; Rose et al., 2007; Boland et al., 2008). Recently, McGovern et al. (2015) reported that ewes supplemented with $26.6 \mathrm{mg} /$ day iodine (either as calcium iodate or potassium iodide) mixed in concentrate feed as a carrier, from 119 days gestation to term, was linked to a failure of $\lg G$ absorption and thus passive transfer which may have been the result of suppressed thyroid hormone status. These results imply there are negative effects of maternal iodine supplementation in late gestation, however, the direct effect on lamb survival and subsequent impact on lamb survival and immune function later in life remain to be established. In ewes fed a 100\% pasture diet, Kerslake et al. (2010) reported no difference in lamb heat production following maternal iodine supplementation (i.m. injection of $1.5 \mathrm{ml}$ iodised peanut oil; Flexidine $26 \% \mathrm{w} / \mathrm{w}$ iodine bound to ethyl esters of unsaturated fatty acids in oil 35 days before mating) despite elevating maternal iodine levels throughout gestation.

Parenteral arginine supplementation of well-fed twinbearing ewes from 100 to 140 days of gestation has been shown to increase brown fat stores in the foetuses at 140 days gestation by about 15\% (McCoard et al., 2013) through increased fat cell hypertrophy, resulting in a $0.6^{\circ} \mathrm{C}$ increase in core-body temperature of twin-born lambs within $2 \mathrm{~h}$ of birth (McCoard et al., 2014a). Increased BAT deposition in foetuses from under-fed ewes and diet-induced obese sheep at 125 days of gestation has also been reported in response to maternal arginine supplementation (Satterfield and $\mathrm{Wu}, 2011$ ). These studies highlight the benefits of maternal arginine supplementation to increase thermoregulatory capacity and potential survival. However, validation of these findings in the field, and quantification of the impacts on lamb survival are required.

The development of BAT and onset of BAT thermogenesis is mediated by rapid up-regulation of genes including UCP-1 around birth (Symonds et al., 2011). Expression of UCP-1 is a marker of BAT thermogenesis and several factors and cofactors influence UCP-1 expression including PPAR $\gamma$ co-activator-1 $\alpha$ (PGC-1 $\alpha$ ) which regulates mitochondrial biogenesis and oxidative metabolism and PRD1-BF-1-RIZ1 homologous domain containing protein-16 (PRDM-16) which is responsible for BAT lineage determination (Kajimura et al., 2010). We have shown that increased BAT mass in late gestation foetuses in response to maternal arginine supplementation is associated with increased expression of UCP-1 and PRDM-16, and that plasma cortisol may up-regulate UCP-1 expression in the near-term ovine foetus (McCoard et al., 2014a). Up-regulation of PRDM16 indicates that arginine may signal the commitment of precursor cells to the BAT lineage which in turn may have important implications maintaining neonatal core-body temperature, as well as mediating whole body metabolism, adipocyte-muscle cross-talk and energy partitioning (Satterfield and Wu, 2011, Tan et al., 2012). Nitrous oxide and mTOR signalling have been implicated in the arginine-induced changes in mitochondrial biogenesis and thus BAT (Tan et al., 2012). In the ovine neonate mTOR signalling may play a greater role (McCoard et al., 2014a); however, this remains to be evaluated directly.

Although non-shivering thermogenesis is the first line of defence against cold exposure in the newborn lamb, the second line of defence is shivering thermogenesis which is initiated only after body temperatures fall significantly (Alexander and Williams, 1968). Shivering thermogenesis can provide up to $50 \%$ of maximal heat production during cold exposure in the newborn lamb. Shivering and nonshivering thermogenesis to facilitate heat production during cold exposure in the newborn lamb are equally important, with shivering thermogenesis becoming the primary source of heat production after the first few days of life (Alexander and Williams, 1968). It has been postulated that adaptation to the extra-uterine environment post-birth may involve cross-talk between different muscle and fat deposits and 
their interaction with other organs involved in BAT function (Symonds, 2013), however these interactions remain to be elucidated. Skeletal muscle and BAT may have a common origin (Seale et al., 2008) and in humans a link between muscle volume and functional BAT has been suggested in children and adolescents (Gilsanz et al., 2011), highlighting the potential importance of skeletal muscle growth during gestation and its contribution to BW thermoregulatory capacity and thus survivability at birth.

Twin-born lambs have reduced muscle mass compared with singletons (McCoard et al., 1997), with the divergence in muscle mass appearing after 100 days gestation (McCoard et al., 2001) contributing to the lower birth weight of twins. During foetal development, skeletal muscle has lower priority, in terms of nutrient partitioning, compared with other tissues such as brain, heart and liver, resulting in muscle being more vulnerable to nutrient deficiency (Zhu et al., 2006). Newborn lambs also exhibit high rates of AA oxidation supporting the notion that low-birth weight lambs at birth are less mature compared with high birth weight lambs in some aspects of metabolic and endocrine development (Greenwood et al., 2002).

Amino acid availability regulates skeletal muscle mass by stimulating protein synthesis and reducing protein degradation. Amino acids act as precursors of nitrogenous substances, such as polyamines and NO which likely mediate growth and development of muscle fibres (Wu et al., 2010). In addition, AA exert a signalling effect on the regulating factors controlling myogenesis (Yoon and Chen, 2013). In the later stages of pregnancy, skeletal muscle growth increases rapidly and the foetus responds to infusion of specific (e.g. arginine) or a mix of AA by increasing protein synthesis (Liechty et al., 1999; de Boo et al., 2005). This response during foetal life appears to be associated with the plasma level of insulin in the foetus (Brown and Hay 2006). However, in IUGR sheep models, when AA are infused directly into the foetus, net foetal protein accretion increases independently of insulin changes (Brown et al., 2012).

Table 1 Summary of the observed effects on foetal-neonatal growth and development when supra-nutritional levels of specific nutrients are supplied to multiple-bearing ewes during mid-to-late pregnancy

\begin{tabular}{|c|c|c|c|}
\hline Interventions & Protocol & Phenotypic effect & Reference \\
\hline \multirow[t]{6}{*}{ Arginine } & $\begin{array}{l}345 \mu \mathrm{mol} \text { Arg- }-\mathrm{HCl} / \mathrm{kg} \text { BW } 3 \text { times daily to from } \\
100 \text { days of gestation to term }\end{array}$ & $\begin{array}{l}\text { Improved placental growth, } \\
\text { development and function }\end{array}$ & van der Linden et al. (2015) \\
\hline & $\begin{array}{l}155 \mu \mathrm{mol} \mathrm{Arg}-\mathrm{HCl} / \mathrm{kg} \text { BW } 3 \text { times daily } \\
\text { between } 60 \text { days gestation and birth }\end{array}$ & $\begin{array}{l}\text { Increased birth weight in single and } \\
\text { twin lambs }\end{array}$ & Lassala et al. (2010) \\
\hline & $\begin{array}{l}345 \mu \mathrm{mol} \mathrm{Arg}-\mathrm{HCl} / \mathrm{kg} \text { BW } 3 \text { times daily to from } \\
100 \text { to } 121 \text { days of gestation }\end{array}$ & $\begin{array}{l}\text { Increased birth weight of } \\
\text { quadruplet lambs }\end{array}$ & Lassala et al. (2011) \\
\hline & $\begin{array}{l}345 \mu \mathrm{mol} \text { Arg- }-\mathrm{HCl} / \mathrm{kg} \text { BW } 3 \text { times a day from } \\
100 \text { days gestation to birth }\end{array}$ & $\begin{array}{l}\text { Increase in birth weight of female } \\
\text { but not male lambs } \\
\text { Increased brown fat stores in the } \\
\text { foetuses }\end{array}$ & McCoard et al. (2013) \\
\hline & $\begin{array}{l}345 \mu \mathrm{mol} \mathrm{Arg}-\mathrm{HCl} / \mathrm{kg} \text { BW } 3 \text { times a day from } \\
100 \text { to } 140 \text { days gestation }\end{array}$ & Increase in core-body temperature & McCoard et al. (2014a) \\
\hline & $\begin{array}{l}345 \mu \mathrm{mol} \text { Arg }-\mathrm{HCl} / \mathrm{kg} \text { BW } 3 \text { times a day from } \\
100 \text { days gestation to birth }\end{array}$ & $\begin{array}{l}\text { Increase in the capacity for protein } \\
\text { synthesis in foetal muscle }\end{array}$ & Sales et al. (2014) \\
\hline \multirow[t]{4}{*}{ lodine } & $\begin{array}{l}100 \text { mg potassium iodide/2 weeks; } 90 \text { days } \\
\text { prepartum }\end{array}$ & Increased rectal temperatures & Donald et al. (1994) \\
\hline & $\begin{array}{l}200 \text { IU/ewe per day in the last } 8 \text { weeks of } \\
\text { gestation }\end{array}$ & No effect on birth weight & Merrell (1998) \\
\hline & $\begin{array}{l}26.6 \mathrm{mg} / \mathrm{day} \text { as calcium iodate or potassium } \\
\text { iodide from } 119 \text { days gestation to term }\end{array}$ & $\begin{array}{l}\text { No effect on birth weight } \\
\text { Failure of } \operatorname{lgG} \text { absorption }\end{array}$ & McGovern et al. (2015) \\
\hline & $\begin{array}{l}\text { I.m injection of } 1.5 \mathrm{ml} \text { iodised peanut oil } \\
35 \text { days pre-mating (long-acting depot) }\end{array}$ & $\begin{array}{l}\text { No effect on birth weight } \\
\text { No effect on heat production }\end{array}$ & Kerslake et al. (2010) \\
\hline \multirow[t]{4}{*}{ Fat } & $\begin{array}{l}2 \%, 4 \% \text { or } 8 \% \text { (of total fat intake) } \\
\text { rumen-protected fat (high in saturated or } \\
\text { monounsaturated fatty acids); } 40 \text { days } \\
\text { prepartum }\end{array}$ & $\begin{array}{l}\text { Increased cold tolerance in } \\
\text { newborn lambs in the } \\
2 \% \text { and } 4 \% \text { groups and reduced } \\
\text { cold tolerance in the } 8 \% \text { group }\end{array}$ & Chen et al. (2007) \\
\hline & PUFA $45 \mathrm{~g} / \mathrm{kg}$ concentrate & Increased lamb vigour & Capper et al. (2006) \\
\hline & $\begin{array}{l}\text { DHA; } 12 \text { g/ewe per day } 9 \text { weeks prepartum for } \\
\text { varying durations }\end{array}$ & $\begin{array}{l}\text { Trend for increased gestation length } \\
\text { Increased lamb vigour }\end{array}$ & $\begin{array}{l}\text { Pickard et al. (2005 and } \\
\text { 2008) }\end{array}$ \\
\hline & $\begin{array}{l}\text { DHA; } 12 \text { g/ewe per day DHA in the last } 30 \text { days } \\
\text { of gestation }\end{array}$ & No effect on birth weight & Keithly et al. (2011) \\
\hline \multirow[t]{2}{*}{ Vitamin $\mathrm{E}$} & 500 mg/kg; 6 weeks prepartum & $\begin{array}{l}\text { Increased lamb birth weight of twin } \\
\text { and triplet }\end{array}$ & Capper et al. (2005) \\
\hline & 360 IU/ewe per day; 6 to 7 weeks prepartum & Decreased rate of stillbirths & Dønnema et al. (2015) \\
\hline
\end{tabular}

IgG = immunoglobulin G; PUFA = polyunsaturated fatty acid. 
During late gestation, changes in specific rather than total intracellular muscle AA concentrations are associated with lower muscle mass in twins (Pacheco et al., 2010). Notably, arginine and glutamine appeared to be closely related to foetal mass and the mass of the semitendinosus muscle (Pacheco et al., 2010). Further, a reduction in the concentration of specific intracellular free $A A$ such as arginine, leucine, valine and glutamine which play important roles in muscle growth, may be limiting for skeletal muscle hypertrophy in twins (Sales et al., 2013), consistent with the correlation between the weight of the foetal semitendinosus muscle in twins with intracellular concentrations of free arginine $(r=0.66, P<0.01)$ and glutamine $(r=0.49$, $P<0.01$ ) in late gestation (Sales et al., 2014).

Compared with singletons, twin foetal sheep have downregulated mTOR signalling in late gestation which may be related to long-term restricted nutrient availability leading to reduced ribosome number and abundance of the translational machinery per ribosome (Sciascia et al., 2010). These results may explain, at least in part, the restricted myofibre hypertrophy and reduced muscle mass observed in twins relative to singletons. Activation of $\mathrm{mTOR}$ signalling in skeletal muscle is under the control of the arginine-family of $A A$ (e.g. arginine and glutamine) and leucine (Meijer and Dubbelhuis, 2004). Consistent with this notion, maternal intravenous bolus injection of arginine three times daily from 100 days gestation to birth increased the capacity for protein synthesis in foetal muscle which is associated with increased abundance of mTOR near birth (Sales, 2014). In the same experiment, we reported that maternal arginine administration increased core-body temperatures of the lambs within $2 \mathrm{~h}$ of birth (McCoard et al., 2014a). Although arginine increased the capacity for skeletal muscle growth in lambs, the potential cross-talk between skeletal muscle growth and thermoregulatory capacity of the lambs remains to be elucidated. Furthermore, the effect of maternal arginine supplementation on lamb survival in pasture-fed ewes in a commercial farm system also remains to be determined.

\section{Future prospects}

Improved productivity and profitability of the sheep meat industry has been made possible by increasing lambing percentages. However, multiple-birth lambs suffer from IUGR which negatively impacts early-life development and growth. The application of specific nutritional components such as AA, vitamins, trace elements and PUFAs in mid-to-late gestation (summarised in Table 1) have the potential to influence traits associated with lamb survival including placental nutrient transfer and thus foetal growth, birth weight, lamb vigour and thermoregulatory capacity. Undoubtedly, further research into the utility of macro and micronutrients in pasture-fed ewes on foetal growth, lamb survival and postnatal performance, critical intervention time windows and identification of delivery routes and stages of growth that are both cost-effective and practical to implement in pasture-based grazing systems should be the focus of future research activities. Further, discovery of the role other nutrients play in regulating foetal growth and survival is required to increase our knowledge of the potential for nutraceuticals to decrease lamb mortality and morbidity. We hope the animal field will grasp this line of research and continue to expand this knowledge base and the potential it has in improving sheep production.

\section{Acknowledgements}

The authors gratefully acknowledge funding support from AgResearch core-funding.

\section{References}

Alexander G 1978. Quantitative development of adipose tissue in foetal sheep. Australian Journal of Biological Sciences 31, 489-504.

Alexander G and Williams D 1968. Shivering and non-shivering thermogenesis during summit metabolism in young lambs. The Journal of Physiology 198, 251-276.

Amer PR, McEwan JC, Dodds KG and Davis GH 1999. Economic values for ewe prolificacy and lamb survival in New Zealand sheep. Livestock Production Science 58, 75-90.

Andrewartha KA, Caple LW, Davies WD and MacDonald JW 1980. Observations on serum thyroxine concentrations in lambs and ewes to assess iodine nutrition. Australian Veterinary Journal 56, 18-21.

Arroyo JA, Brown LD and Galan HL 2009. Placental mammalian target of rapamycin and related signaling pathways in an ovine model of intrauterine growth restriction. American Journal of Obstetrics and Gynecology 201, 616. e1-e7.

Ashworth CJ, Dwyer CM, Mcllvaney K, Werkman M and Rooke JA 2011. Breed differences in fetal and placental development and feto-maternal amino acid status following nutrient restriction during early and mid pregnancy in Scottish Blackface and Suffolk sheep. Reproduction, Fertility and Development 23, 1024-1033.

Boland TM, Callan JJ, Brophy PO, Quinn PJ and Crosby TF 2006. Lamb serum vitamin $\mathrm{E}$ and immunoglobulin $\mathrm{G}$ concentrations in response to various maternal mineral and iodine supplementation regimens. Animal Science 82, 319-325.

Boland TM, Hayes L, Sweeney T, Callan JJ, Baird AW, Keely S and Crosby TF 2008. The effects of cobalt and iodine supplementation of the pregnant ewe diet on immunoglobulin G, vitamin E, T3 and T4 levels in the progeny. Animal 2, 197-206.

Brown LD and Hay WW 2006. Effect of hyperinsulinemia on amino acid utilization and oxidation independent of glucose metabolism in the ovie fetus. American Journal of Physiology - Endocrinology and Metabolism 291, E1333-E1340.

Brown LD, Rozance PJ, Thorn SR, Friedman JE and Hay WW 2012. Acute supplementation of amino acids increases net protein accretion in IUGR fetal sheep. American Journal of Physiology - Endocrinology and Metabolism 303, E352-E364.

Capobianco E, Ramirez VI, Fornes D, Powell TL, Jansson PT and Jawerbaum A 2015. Activation of mTOR signaling and increased nitric oxide metabolism in the placenta of rats with gestational diabetes. Placenta 36, 516.

Capper JL, Wildinson RG, Kasapidou E, Pattinson SE, Mackenzie AM and Sinclair LA 2005. The effect of dietary vitamin E and fatty acid supplementation of pregnant and lactating ewes on placental and mammary transfer of vitamin $E$ to the lamb. The British Journal of Nutrition 93, 549-557.

Capper JL, Wilkinson RG, Mackenzie AM and Sinclair LA 2006. Polyunsaturated fatty acid supplementation during pregnancy alters neonatal behaviour in sheep. The Journal of Nutrition 136, 397-403.

Chen CY, Carstens GE, Gilbert CD, Theis CM, Archibeque SL, Kurz MW, Slay LJ and Smith SB 2007. Dietary supplementation of high levels of saturated and monounsaturated fatty acids to ewes during late gestation reduces thermogenesis in newborn lambs by depressing fatty acid oxidation in perirenal brown adipose tissue. The Journal of Nutrition 137, 43-48. 
Dalton DC, Knight TW and Johnson DL 1980. Lamb survival in sheep breeds on New Zealand hill country. New Zealand Journal of Agricultural Research 23, 167-173.

Daniels JT, Hatfield PG, Burgess DE, Kott RW and Bowman JG 2000. Evaluation of ewe and lamb immune response when ewes were supplemented with vitamin E. Journal of Animal Science 78, 2731-2736.

De Boo HA, van Sijl PL, Smith DEC, Kuik W, Lafeber HN and Harding JE 2005. Arginine and mixed amino acids increase protein accretion in the growth restricted and normal ovine fetus by different mechanisms. Pediatric Research 85, 1575-1583.

Donald GE, Langlands JP, Bowles JE and Smith AJ 1994. Subclinical selenium insufficiency. 6. Thermoregulatory ability of perinatal lambs born to ewes supplemented with selenium and iodine. Australian Journal of Experimental Agriculture 34, 19-24.

Dønnema I, Randbya AT, Hektoenb L, Avdemc F, Meling S, Våge ÅØ, Ådnøya T, Steinheima $G$ and Waage S 2015. Effect of vitamin E supplementation to ewes in late pregnancy on the rate of stillborn lambs. Small Ruminant Research $125,154-162$.

Dwyer CM 2007. The welfare of the neonatal lamb. Small Ruminant Research $76,31-41$.

Dwyer CM, Conington J, Corbiere F, Holmoy IH, Muri K, Nowak R, Rooke J, Viopond J and Gautier J-M 2016. Invited review: improving neonatal survival in small ruminants: science into practice. Animal 10, 449-459.

Dwyer CM and Morgan CA 2006. Maintenance of body temperature in the neonatal lamb: effects of breed, birth weight, and litter size. Journal of Animal Science 84, 1093-1101.

Ergaz Z, Avgil M and Ornoy A 2005. Intrauterine growth restriction - etiology and consequences: what do we know about the human situation and experimental animal models? Reproductive Toxicology 20, 301-322.

Everett-Hincks J and Dodds K 2008. Management of maternal-offspring behavior to improve lamb survival in easy care sheep systems. Journal of Animal Science 86, E259-E270.

Everett-Hincks J, Lopez-Villalobos N, Blair H and Stafford K 2005. The effect of ewe maternal behaviour score on lamb and litter survival. Livestock Production Science 93, 51-61.

Fleming T, Velazquez M, Eckert J, Lucas E and Watkins A 2012. Nutrition of females during the peri-conceptional period and effects on foetal programming and health of offspring. Animal Reproduction Science 130, 193-197.

Ford S 2000. Cotyledonary placenta. In Encyclopedia of Reproduction (ed. J Neill and E Knobil), pp. 730-738. Academic Press, San Diego, CA, USA.

Fowden A, Ward J, Wooding F, Forhead A and Constancia M 2006. Programming placental nutrient transport capacity. The Journal of Physiology 572, 5-15.

Gilsanz V, Chung SA, Jackson H, Dorey FJ and Hu HH 2011. Functional brown adipose tissue is related to muscle volume in children and adolescents. Journal of Pediatrics 158, 722-726.

Gootwine E, Spencer TE and Bazer FW 2007. Litter-size-dependent intrauterine growth restriction in sheep. Animal 1, 547-564.

Grace ND and Knowles SO 2010. lodine. In Managing mineral deficiencies in grazing livestock (ed. ND Grace, SO Knowles and AR Sykes), pp. 95-105. New Zealand Society of Animal Production, Hamilton, New Zealand.

Grace ND and Knowles SO 2012. Trace element supplementation of livestock in New Zealand: meeting the challenges of free-range grazing systems. Veterinary Medicine International 2012, 1-8.

Greenwood PL, Hunt AS, Slepetis RM, Finnerty KD, Alston C, Beermann DH and Bell AW 2002. Effects of birth weight and postnatal nutrition on neonatal sheep: III. Regulation of energy metabolism. Journal of Animal Science 80, 2850-2861.

Hammer CJ, Thorson JF, Meyer AM, Redmer DA, Luther JS, Neville TL, Reed JJ, Reynolds LP, Caton JS and Vonnahme KA 2011. Effects of maternal selenium supply and plane of nutrition during gestation on passive transfer of immunity and health in neonatal lambs. Journal of Animal Science 89, 3690-3698.

Hinch GN and Brien F 2014. Lamb survival in Australian flocks: a review. Animal Production Science 54, 656-666.

Hodgson J, Cameron K, Clark D, Condron I, Fraser T, Hedley M, Holmes C Kemp P, Lucas R, Moot D, Morris S, Nicholas P, Shadbolt N, Sheath G, Valentine I, Waghorn G and Woodfield D 2005. New Zealand's pastoral industries: efficient use of grassland resources. In Grasslands developments, opportunities, perspectives (ed. SG Reynolds and J Frame), pp. 181-205. Science Publication, New Hampshire, USA.
Huber JT 1988. Vitamins in ruminant nutrition. In The ruminant animal: digestive physiology and nutrition (ed. DC Church), pp. 313-325. Prentice Hall, Englewood Cliffs, NJ, USA.

Ito N, Ruegg UT, Kudo A, Miyagoe-Suzuki Y and Takeda S 2013. Activation of calcium signaling through Trpv1 by nNOS and peroxynitrite as a key trigger of skeletal muscle hypertrophy. Nature Medicine 19, 101-106.

Jansson T and Powell TL 2006. Human placental transport in altered fetal growth: does the placenta function as a nutrient sensor? - a review. Placenta 27 (suppl. A), 91-97.

Kajimura S, Seale P and Spiegelman BM 2010. Transcriptional control of brown fat development. Cell Metabolism 11, 257-262.

Keithly Jl, Kott RW, Berardinelli JD, Moreaux S and Hatfield PG 2011. Thermogenesis, blood metabolites and hormones, and growth of lambs born to ewes supplemented with algae-derived docosahexanenoic acid. Journal of Animal Science 89, 4305-4313.

Kenyon P 2008. A review of in-utero environmental effects on sheep production. Proceedings of the New Zealand Society of Animal Production 68, 142-155.

Kenyon PR and Blair HT 2014. Foetal programming in sheep - effects on production. Small Ruminant Research 118, 16-30.

Kerslake JI, Kenyon PR, Stafford KJ, Morris ST and Morel PCH. 2010. Can maternal iodine supplementation improve twin- and triplet-born lamb plasma thyroid hormone concentrations and thermoregulation capabilities in the first 24-36 h of life? Journal of Agricultural Science 148, 453-463.

Kim J-Y, Burghardt RC, Wu G, Johnson GA, Spencer TE and Bazer FW 2011. Select nutrients in the ovine uterine lumen. VIII. Arginine stimulates proliferation of ovine trophectoderm cells through MTOR-RPS6K-RPS6 signaling cascade and synthesis of nitric oxide and polyamines. Biology of Reproduction 84, 70-78.

Kivimae A and Carpena C 1973. The level of vitamin E content in some conventional feeding stuffs and the effects of genetic ariety, harvesting, processing and storage. Acta Agriculture Scandanavia 19 (suppl.), 161-168.

Knowles SO and Grace ND 2015. Serum total iodine concentrations in pasture-fed pregnant ewes and newborn lambs challenged by iodine supplementation and goitrogenic kale. Journal of Animal Science 93, 425-432. Kwon H, Ford SP, Bazer FW, Spencer TE, Nathanielsz PW, Nijland MJ, Hess BW and Wu G 2004. Maternal nutrient restriction reduces concentrations of amino acids and polyamines in ovine maternal and fetal plasma and fetal fluids. Biology of Reproduction 71, 901-908.

Kwon H, Spencer TE, Bazer FW and Wu G 2003. Developmental changes of amino acids in ovine fetal fluids. Biology of Reproduction 68, 1813-1820.

Lammoglia MA, Bellows RA, Grings EE and Bergman JW 1999. Effects of prepartum supplementary fat and muscle hypertrophy genotype on cold tolerance in newborn calves. Journal of Animal Science 77, 2227-2233.

Lane J, Jubb T, Shephard R, Webb-Ware J and Fordyce G 2015. Priority list of endemic diseases for the red meat industries. Meat and Livestock Australia Final Report B.AHE.0010, 20 March 2015, North Sydney, New South Wales, Australia.

Lassala A, Bazer FW, Cudd TA, Datta S, Keisler DH, Satterfield MC, Spencer TE and Wu G 2010. Parenteral administration of L-arginine prevents fetal growth restriction in undernourished ewes. The Journal of Nutrition 140, 1242-1248.

Lassala A, Bazer FW, Cudd TA, Datta S, Keisler DH, Satterfield MC, Spencer TE and Wu G 2011. Parenteral administration of L-arginine enhances fetal survival and growth in sheep carrying multiple fetuses. The Journal of Nutrition 141, 849-855.

Liechty EA, Boyle DW, Moorehead H, Auble L and Denne SC 1999. Aromatic amino acids are utilized and protein synthesis is stimulated during amino acid infusion in the ovine fetus. The Journal of Nutrition 129, 1161-1166.

McCoard S, Henderson HV, Knol FW, Dowling SK and Webster JR 2014b. Infrared thermal imaging as a method to study thermogenesis in the neonatal lamb. Animal Production Science 54, 1497-1501.

McCoard S, Sales F, Wards N, Sciascia Q, Oliver M, Koolaard J and van der Linden D 2013. Parenteral administration of twin-bearing ewes with L-arginine enhances the birth weight and brown fat stores in sheep. SpringerPlus 2, 684 .

McCoard S, Wards N, Koolaard J and Salerno MS 2014a. The effect of maternal arginine supplementation on the development of the thermogenic program in the ovine fetus. Animal Production Science 54, 1843-1847.

McCoard SA, McNabb WC, Birtles MJ, Harris PM, McCutcheon SN and Peterson SW 2001. Immunohistochemical detection of myogenic cells in muscles of fetal and neonatal lambs. Cells Tissues Organs 169, 21-33. 
McCoard SA, Peterson SW, McNabb WC, Harris PM and McCutcheon SN 1997 Maternal constraint influences muscle fibre development in fetal lambs. Reproduction, Fertility and Development 9, 675-681.

McCoard SA, Sales FA and Sciascia QL 2016. Amino acids in sheep production. Frontiers in Bioscience, Elite 8, 264-288.

McGovern FM, Magee DA, Browne JA, MacHugh DE and Boland TM 2015. lodine supplementation of the pregnant dam alters intestinal gene expression and immunoglobulin uptake in the newborn lamb. Animal, https://doi.org/ 10-.1017/S1751731115002505

Meijer AJ and Dubbelhuis PF 2004. Amino acid signalling and the integration of metabolism. Biochemical and Biophysical Research Communications 313, 397-403.

Mellor D 1983. Nutritional and placental determinants of foetal growth rate in sheep and consequences for the newborn lamb. The British Veterinary Journal $139,307-324$

Merrell BC 1998. The effects of lamb survival rate of supplementing ewes with vitamin E during late pregnancy. Proceedings of Sheep Veterinary Society, Spring Meeting, Scarborough, Youdshire, UK, pp. 57-61.

Morel PCH, Morris ST and Kenyon PR 2008. Effect of birthweight on survival in triplet-born lambs. Australian Journal of Experimental Agriculture 48 984-987.

Morris ST and Kenyon PR 2004. The effect of litter size and sward height on ewe and lamb performance. New Zealand Journal of Agricultural Research 48, 275-286.

Morris ST and Kenyon PR 2014. Intensive sheep and beef production from pasture - a New Zealand perspective of conerns, opportunities and challenges. Meat Science 98, 330-335.

Oliver MH, Jaquiery AL, Bloomfield FH and Harding JE 2007. The effects of maternal nutrition around the time of conception on the health of the offspring. Society of Reproduction and Fertility Supplement 64, 397-410.

Pacheco D, Treloar BP, Kenyon PR, Blair HT and McCoard S 2010. Brief communication: intracellular concentrations of free amino acids are reduced in skeletal muscle of late gestation twin compared to single fetuses. Proceedings of the New Zealand Society of Animal Production 70, 199-201.

Pickard RM, Beard AJ, Seal CJ and Edwards SA 2005. Supplementation of ewe diets with algal biomass rich in docosahexaenoic acid for different time periods before lambing affects measures of lamb viability. Proceedings of the British Society of Animal Science, 89pp.

Pickard RM, Beard AP, Seal CJ and Edwards SA 2008. Neonatal lamb vigour is improved by feeding docosahexaenoic acid in the form of algal biomass during late gestation. Animal 2, 1186-1192.

Quirk MF and Norton BW 1987. The relationship between the cobalt nutrition of ewes and the vitamin B12 status of ewes and their lambs. Australian Journal of Agricultural Research 38, 1071-1082.

Rooke JA, Dwyer CM and Ashworth CJ 2008. The potential for improving physiological, behavioural and immunological responses in the neonatal lamb by trace element and vitamin supplementation of the ewe. Animal 2 , 514-524.

Roos S, Jansson N, Palmberg I, Säljö K, Powell TL and Jansson T 2007. Mammalian target of rapamycin in the human placenta regulates leucine transport and is down-regulated in restricted fetal growth. The Journal of Physiology 582, 449-459.

Roos S, Palmberg I, Säljö K, Powell TL and Jansson T 2005. Expression of placental mammalian target of rapamycin (mTOR) is altered in relation to fetal growth and mTOR regulates leucine transport. Placenta 26, A9.

Rose MT, Wolf BT and Haresign W 2007. Effect of the level of iodine in the diet of pregnant ewes on the concentration of immunoglobulin $\mathrm{G}$ in the plasma of neonatal lambs following the consumption of colostrum. British Journal of Nutrition 97, 315-320.

Rosenfeld CR, Cox BE, Roy T and Magness RR 1996. Nitric oxide contributes to estrogen-induced vasodilation of the ovine uterine circulation. Journal of Clinical Investigation 98, 2158-2166.

Rowland JP, Salman MD, Kimberling CV, Schweitzer DJ and Keefe TJ 1992. Epidemiologic factors involved in perinatal lamb mortality on four range sheep operations. American Journal of Veterinary Research 53, 262-267.

Rumball C, Harding J, Oliver M and Bloomfield F 2008. Effects of twin pregnancy and periconceptional undernutrition on maternal metabolism, fetal growth and glucose - insulin axis function in ovine pregnancy. The Journal of Physiology 586, 1399-1411.
Sales F 2014. Amino acids and skeletal muscle growth in lambs. PhD thesis, Massey University, Palmerston North, New Zealand.

Sales F, Pacheco D, Blair H, Kenyon P and McCoard S 2013. Muscle free amino acid profiles are related to differences in skeletal muscle growth between single and twin ovine fetuses near term. SpringerPlus 2, 1-9.

Sales F, Pacheco D, Blair $H$, Kenyon P, Nicholas G, Senna Salerno M and McCoard S 2014. Identification of amino acids associated with skeletal muscle growth in late gestation and at weaning in lambs of well-nourished sheep. Journal of Animal Science 92, 5041-5052.

Sargison ND, West DM and Clark RG 1998. The effects of iodine deficiency on ewe fertility and perinatal lamb mortality. New Zealand Veterinary Journal 46, 72-75. Satterfield M and Wu G 2011. Growth and development of brown adipose tissue: significance and nutritional regulation. Frontiers in Bioscience $16,1589-1608$

Satterfield MC, Bazer FW, Spencer TE and Wu G 2010. Sildenafil citrate treatment enhances amino acid availability in the conceptus and fetal growth in an ovine model of intrauterine growth restriction. Journal of Nutrition 140, $251-258$

Scales GH, Burton RN and Moss RA 1986. Lamb mortality, birth weight and nutrition in late pregnancy. New Zealand Journal of Agricultural Research 29, 75-82.

Sciascia Q, Pacheco D, Bracegirdle J, Berry C, Kenyon P, Blair $H$, Senna Salerno M, Nicholas G and McCoard S 2010. Brief communication: effects of restricted fetal nutrition in utero on mTOR signalling in ovine skeletal muscle. Proceedings of the New Zealand Society of Animal Production 70, 180-182.

Seale P, Bjork B, Yang W, Kajimura S, Chin S, Kuang S, Scimè A, Devarakonda S, Conroe HM, Erdjument-Bromage $H$, Tempst $P$, Rudnicki MA, Beier DR and Spiegelman BM 2008. PRDM16 controls a brown fat/skeletal muscle switch. Nature 454, 961-967.

Shorten PR, O'Connell AR, Demmers KJ, Edwards SJ, Cullen NG and Juengel JL 2013. Effect of age, weight, and sire on embryo and fetal survival in sheep. Journal of Animal Science 91, 4641-4653.

Stafford KJ 2013. Welfare of sheep and goats. Animal welfare in New Zealand. Occasional publication no 16. New Zealand Society of Animal Production Cambridge, New Zealand, pp. 56-71.

Stafford KJ, Kenyon PR, Morris ST and West DM 2007. The physical state and metabolic status of lambs of different birth rank soon after birth. Livestock Science 111, 10-15.

Stoewsand GS 1995. Bioactive organosulfur phytochemicals in Brassica oleracea vegetables - a review. Food Chemistry and Toxicology 33, 537-543.

Symonds ME 2013. Brown adipose tissue growth and development. Scientifica https://doi.org/10.1155/2013/305763

Symonds ME and Lomax MA 1992. Maternal and environmental influences on thermoregulation in the neonate. Proceedings of the Nutrition Society 51, 165-172.

Symonds ME, Sebert SP and Budge $H$ 2010. Nutritional regulation of fetal growth and implications for productive life in ruminants. Animal 4, 1075-1083.

Symonds ME, Sebert $S$ and Budge $H$ 2011. The obesity epidemic: from the environment to epigenetics - not simply a response to dietary manipulation in a thermoneutral environment. Frontiers in Genetics 2, 24.

Tan XL, Yin Y, Wu Z, Liu C, Tekwe CD and Wu G 2012. Regulatory roles for L-arginine in reducing white adipose tissue. Frontiers in Bioscience 17, 2237.

van der Linden D, Sciascia Q, Sales F and McCoard S 2013. Placental nutrient transport is affected by pregnancy rank in sheep. Journal of Animal Science 91, 644-653.

van der Linden D, Sciascia Q, Sales F, Wards NJ, Oliver MH and McCoard SA 2015. Intravenous maternal $L$-arginine administration to twin-bearing ewes during late pregnancy enhances placental growth and development. Journal of Animal Science 93, 4917-4925.

Vonnahme KA, Evoniuk J, Johnson ML, Borowicz PP, Luther JS, Pant D, Redmer DA, Reynolds LP and Grazul-Bilska AT 2008. Placental vascularity and growth factor expression in singleton, twin, and triplet pregnancies in the sheep. Endocrine 33, 53-61.

Vonnahme KA, Lemley CO, Caton JS and Meyer AM 2015. Impacts of maternal nutrition on vascularity of nutrient transferring tissues during gestation and lactation. Nutrients 7, 3497-3523.

West DM, Bruere AN and Ridler Al 2008. The sheep: health, disease and production, (3rd edition). Vet Learn Foundation, Wellington, New Zealand. 
McCoard, Sales and Sciascia

Wu G, Bazer FW, Burghardt RC, Johnson GA, Kim SW, Li XL, Satterfield MC and Spencer TE 2010. Impacts of amino acid nutrition on pregnancy outcome in pigs: mechanisms and implications for swine production. Journal of Animal Science 88, E195-E204.

Wu G, Bazer FW, Wallace JM and Spencer TE 2006. Board-invited review: intrauterine growth retardation: implications for the animal sciences. Journal of Animal Science 84, 2316-2337.
Yoon M-S and Chen J 2013. Distinct amino acid-sensing mTOR pathways regulate skeletal myogenesis. Molecular Biology of the Cell 24, 3754-3763.

Zhu MJ, Ford SP, Means WJ, Hess BW, Nathanielsz PW and Du M 2006. Maternal nutrient restriction affects properties of skeletal muscle in offspring. Journal of Physiology 575, 241-250. 